\title{
Corporate Governance Mechanisms and Jordanian Companies' Financial Performance
}

\author{
Tariq Tawfeeq Yousif Alabdullah ${ }^{1}$, Sofri Yahya ${ }^{2} \&$ Thurasamy Ramayah ${ }^{3}$ \\ ${ }^{1}$ College of Administration and Economics, Accounting Department, University of Basrah, Iraq \\ ${ }^{2}$ Graduate School of Business, University Sains Malaysia, Penang, Malaysia \\ ${ }^{3}$ School of Management, University Sains Malaysia, Penang, Malaysia \\ Correspondence: Tariq Tawfeeq Yousif Alabdullah, School of Management, University Sains Malaysia, 11800 \\ USM, Penang, Malaysia. E-mail: tariqtariq1984@gmail.com
}

\author{
Received: August 16, 2014 Accepted: September 13, 2014 Online Published: October 30, 2014 \\ doi:10.5539/ass.v10n22p247 URL: http://dx.doi.org/10.5539/ass.v10n22p247
}

\begin{abstract}
Previous studies in the literature review that dealt with corporate governance have recently witnessed significant growth that led to some new trends. The purpose of the current paper is to significantly contribute to such trends through investigating and analyzing the effect of corporate governance mechanisms on firm's financial performance for a sample consisting of industrial and service companies in Jordan. The current study examined cross sectional data through 109 companies (industrial and service companies). The study uses the annual reports for the fiscal year 2011 of the most active Jordanian companies in order to examine the predictions of corporate governance effects on financial performance. This cross sectional study tested all hypotheses of the study and used statistical software, SPSS 20, to analyze data. The findings indicated that board size has a negative association with firm financial performance. Furthermore, the empirical investigations for the current study revealed that the presence of independent directors in the board is not associated with financial performance. Likewise, the result showed that CEO duality has no impact on firm financial performance. From developed and developing countries' perspective, the current paper uniquely contributes to the literature that dealt with corporate governance and firm performance throughout introducing a market share variable as a measurement to represent firm's financial performance. In doing so, the paper is the first of its kind to provide new insights on the relationship between corporate governance and firm performance. It therefore provides a new indicator considered as extending for prior research in this discipline as, to the best of researcher's knowledge; no prior work has been done in both developed and developing economies including Jordan. The study provides empirical evidence to the academic, policy makers and all beneficiary parties of stakeholders in the Middle East, specifically Jordan.
\end{abstract}

Keywords: corporate governance, board size, independent board, CEO duality, financial performance, market share, Jordan

\section{Introduction}

Globally, corporate governance has got wide attention due to the crises and scandals faced by so many countries, such as Adelphia, Enron and WorldCom, and other scandals. All have contributed, as mentioned by Brown et al. (2006), to encouraging the companies in the whole world to pursue to get strong corporate governance in their companies. Good corporate governance leads to better firm valuation and enhancing its performance, in that firms dealing with better practices of corporate governance should perform better than those having worse corporate governance practices (Simmons, 2004; Franck \& Sundgren, 2012). Several previous studies in the literature have studied and investigated the relationship between corporate governance and firm performance due to the fact that the importance of corporate governance to improve companies condition from one hand and the revival of the economic from the other hand.

Despite the fact that corporate governance is a one control system that has clear principles and mechanisms, still there is no unique concept to describe it within one philosophical framework (Alabdullah et al., 2014). Thus, there is a variety of definitions of corporate governance shown by the previous studies in the literature. For instance, Cadbury Report (1992) considered corporate governance as a control system which directed and 
controlled a company. Guo et al., (2013) illustrate that Corporate Governance is concerned with the relationship between stockholders (the principal) and management (the agent). They show that, focus on such issue is to limit and manage the potential conflict between these two parties. In the same vein, Solomon \& Solomon (2003) admit that the majority of scholars are in the same line and totally agree with the core idea that corporate governance is a set of mechanisms and a control process that pursue to make the management act in the best interest of stockholders. Eiteman et al. (2009) demonstrate corporate governance as representing the relationship among stakeholders used to identify and control firm's strategic direction and performance.

Corporate governance represented by its mechanisms is an important and vital instrument that its role lies in/focuses on controlling the corporation and arranging its accountability. In addition, corporate governance is not only useful for stockholders, but also it is useful for all parties of the stakeholders (Aras \& Crowther, 2008). Bearing in mind that corporate governance is precise and ancient control system that has deep roots. Its roots ancient and back to a hundred of years which means that its principles had implicit presence that had not applied directly nor had legislation, law, and even special name (Alabdullah et al., 2014).

The current study is important due to the fact that there is an internationally growing trend that could be recognized of the value of corporate governance system for a firm's success, given that several institutions and countries have issued recommendations and guidelines for best corporate governance practices and board composition. Moreover, corporate governance is considered as an extension to what agency theory principles have been tried to solve the eternal conflict between the managers (agent) and the stockholders (principal). Thus, especially after the global crisis, the use of sound implementation of corporate governance has become so important to be implemented by regulators and leaders of the organizations to avoid occurring other potential crisis or even to limit its effect on one hand, and to enhancement firm performance on the other hand.

The primary objective of the present study is to contribute uniquely to enriching the body of knowledge in the management and accounting discipline through investigating the relationship between corporate governance mechanisms and firm's financial performance in both developed the developing countries, specifically in Jordanian context. Thus, it contributes to the existing literature in different ways. Firstly, there is no previous study that chose market share as a measurement and indicator of firm performance in developed countries in general, nor in developing ones including Jordan in particular. Secondly, there is gab in the findings of previous studies that dealt with corporate governance and firm performance is inconclusive. Some of them found that the relationship between corporate governance mechanisms is positive relation, and others found that such relation is negative, while other group found there is no relationship between corporate governance and firm performance. Consequently, this calls for the dire need from the researchers to investigate another measurement of firm performance. Thus, Market share is the measurement used by the current study to refer to financial performance which has never been used before in the literature. Finally, as mentioned by Al-Qaisi (2013), there is a lack of performance facing the companies that belong to non-financial sector in Jordan.

The sample of this current study consists of 109 non-financial companies whose 2011 annual reports are available with no missing data on Amman Stock Exchange website; for Jordanian industrial and service companies. The Corporate Governance mechanisms chosen in the current study are represented by board size, independent board, and CEO duality to investigate their relationship with firm financial performance which lies in market share.

The remainder of the present study is structured in the following way. Section 2 reviews briefly the firm performance which is followed by explaining the relationship between corporate governance and firm performance including the prior work of each corporate governance mechanism selected in the present study and their relationship with firm performance as argued by previous studies in the literature. This is followed by Section 3 which discusses source of data collection and measurement of variables through the methodology. In Section 4, the result and discussion will be presented. Finally, Section 5 will be the conclusion and limitation of the study.

\section{Literature Review and Research Hypotheses}

\subsection{Firm Performance}

Firm performance has been investigated in the accounting/management literature based on agency theory as a major dependent variable that would be achieved and enhanced as an important goal (Bauer et al., 2008; Haniffa \& Hudaib, 2006; Klapper \& Love, 2004). The main purpose of firm performance that stems from its concept is to consolidate the efficiency and effectiveness of the company and achieve its objectives being the main concern for the firm in the long run to survive (Al-Hawary, 2011; Zehir et al., 2011). 
A widespread body of literature about firm performance has been published over the past few decades. Firm performance has increasingly become a very important issue by the scholars and researchers due to its positive impact on enhancing the economy and solving its social problems and eliminating unemployment (Palacios-Marqués et al., 2013; Cooke, 2001). Thus, recently there have been a wave of intensive studies in developed countries that focused on/investigated the firm performance (Clarke et al., 2011; Garay \& González, 2008; Hiraki et al., 2003; Mazzanti et al., 2006) Nonetheless, a little attention has been given for firm performance in the developing countries especially in Jordan (Al-Haddad et al., 2011; Al-Hawary, 2011).

Martinsons et al. (1999) mentioned that drawback and lack in most of previous studies is represented by using traditional methods in measuring financial performance such as ROA, ROE, etc. Marr \& Schiuma (2003) mentioned that there is a weakness in the procedure of firm performance measurement. Thus, the current study is the first to investigate the relationship between corporate governance and financial performance measuring via market share, where no previous study did so. Market share variable is selected mainly to represent firm performance because the study believes that market share has a significant role to do so. This belief is in line with previous studies (Oxenfeldt, 1959; Hansen \& Wernerfelt, 1989; Mayer, 1997; Eccles, 1990; Zehir et al., 2011) which note that a market share's role is a very important item that might be represented by firm performance. For example, Mayer (1997) shows that market share could be a measurement for firm performance. Moreover, Oxenfeldt (1959) admits that market share is an effective appraisal instrument measurement that refers to firm and management performance. In the same assertion, (Eccles, 1990; Hansen \& Wernerfelt, 1989) assure that market share is a proxy to measure firm performance. In addition, Zehir et al. (2011) point out that companies give more attention to measure their performance because it reflects their activities, shows market share, and achieves profitability. Thus, based on the assertions and recommendations in the literature, the current study pursues to use market share to represent firm's financial performance because as, Hoque \& James (2000) assert that in case a firm has a good market share, the firm will have market position demand to internal communication system that enhances the picture of firm performance. Choosing market share is valid to be used in the present study because as argued by Oxenfeldt (1959), market share indicator is valid and more suitable in the safety country that characterized by its stable market. Thus, this is quite suitable in the Jordanian context. Jordan is considered as one of competing and stable countries in the region due to its highly safety and stability (Alkhatib \& Marji, 2012).

\subsection{Corporate Governance and Firm Performance}

Corporate Governance is concerned with how to prepare the structure, procedures and mechanisms by which activities of a firm are managed, in that to maximize the shareholder worth through responsibility of managers and consolidating firm performance. Chen et al. (2009) argue that recently the empirical evidence in the literature supports the notion that corporate governance limits agency cost, leading to reinforce the viewpoint: the better the CG, the more improved the performance and the higher the firm value.

A substantial body of literature on the firm performance/value providing empirical evidence has been published over the past few decades (see Clarke et al., 2011; Cui \& Mak, 2002; Hiraki et al., 2003; Jensen \& Meckling, 1976; Makhamreh, 2000; Mazzanti et al., 2006). What stands out in the literatures dealing with performance/value and its relationship with corporate governance system is the multiplicity of views which lead to different results obtained from this relationship. Some of literature stream, done in different parts of the world, supports the notion that corporate governance is crucial, positive, and significant in its relationship with firm performance (see Abor \& Biekpe, 2007; Al-Haddad et al., 2011; Andres \& Vallelado, 2008; Balasubramanian et al., 2010; Black et al., 2006; Chen et al., 2009; Cheung et al., 2007; Chhibber \& Majumdar, 1997; Dittmar \& Mahrt-Smith, 2007; Durnev \& Kim, 2005; Garay \& González, 2008; Gedajlovic \& Shapiro, 2002; Gompers et al., 2003; Hiraki et al., 2003; Jaafar \& El-Shawa, 2009; Kim et al., 2012; Klapper \& Love, 2004; Tornyeva \& Wereko, 2012; Zheka, 2006). For example, Klapper \& Love (2004) conduct their study across fourteen emerging countries with a number of 374 firms. The performance and value metrics they used were Tobin's Q and return on assets (ROA). They find a positive association between the quality of corporate governance and firm performance and market value. Zheka (2006) shows that the relationship between the quality of corporate governance and enterprise performance is causal and positive. Their sample survey was on Ukraine firms using the net revenue as measure of firm performance. On the other hand, negative finding between corporate governance and firm performance could be seen in previous studies (see Agrawal \& Knoeber, 1998; Bauer, Guenster, \& Otten, 2004; Haniffa \& Hudaib, 2006; Jensen, 1993; Mak \& Kusnadi, 2005; Yermack, 1996). However, other findings from other previous studies in the literature such as, Heracleous (2001) who confirms the relationship between corporate governance best practices represented by the mechanisms of duality of chief executive officer/Chairman and the composition of the insider and outsider in the firm and firm performance. 
The findings show that such a relationship is insignificant. Due to this gap in the literature, and according to what has been argued by Marr \& Schiuma (2003), they demonstrate that despite the extensive trends towards measurement of firm performance that have been studied by several researchers in the literature and used so many new approaches for firm performance measurement, yet the discipline of firm performance measurement still needs more deliberations and contributions to recover and overcome the lack in firm performance's measurements. Hence, the current study contributes to the field of firm performance by choosing a suitable indicator to measure financial performance.

\subsection{Theoretical Framework and Hypotheses Development}

The framework for current study is shown in Figure 1. The independent variable in the current study is corporate governance represented by its board composition' mechanisms, namely board size, board independence, and CEO duality. The dependent variable is firm performance represented by market share. In addition, the control variable is firm size. We predict the hypotheses of this study according to previous studies in the literature review as follows.

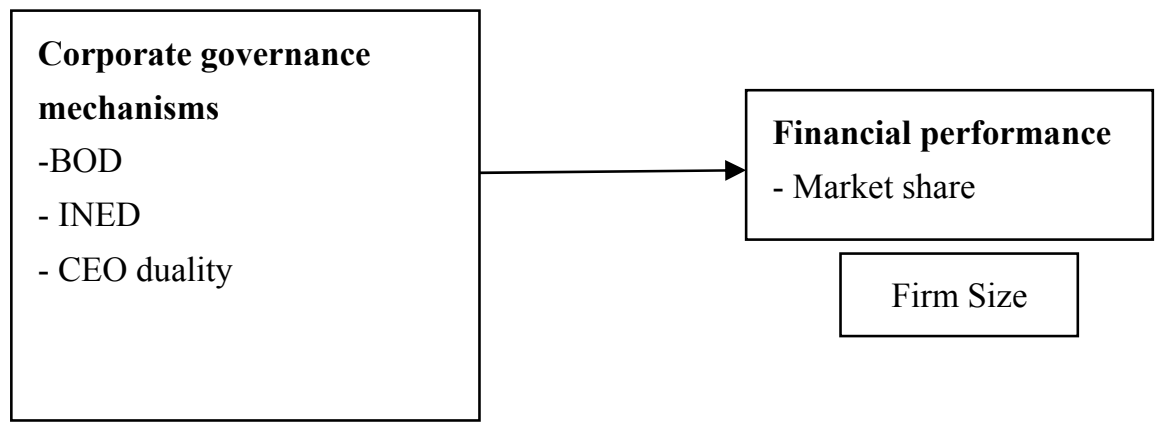

Figure 1. Theoretical framework

\subsubsection{Board Size and Firm Performance}

Board of directors is one of essential and unique components of both board dynamics and overall quality of corporate governance mechanisms that oversees the company's business conduct to ensure it is properly managed by their agents and to reduce agency cost (Hassan \& Ahmed, 2012; Mkrtchyan, 2013; Shleifer \& Vishny, 1997). There is a consensus in the previous studies in the literature that illustrate and admit that the effectiveness of board of directors can be achieved based on the level of expertise and knowledge (Mkrtchyan, 2013). Diversified viewpoints have been reviewed in the findings of the previous studies about effectiveness of the board of directors. Some studies find that the small board size can lead to better and particular outcome than the larger one. Such a viewpoint proposed that the small size of the board of directors is more effective than the larger board for increased communication and coordination problems. Moreover, it might lead to decrease poor decisions made by a large group of the board (see Adnan et al., 2011; Haniffa \& Hudaib, 2006; Jensen, 1993; Kumar \& Singh, 2013; Mak \& Kusnadi, 2005; Mashayekhi \& Bazaz, 2008; Rashid et al., 2010; Yermack, 1996). On the other hand, other viewpoints in the previous studies demonstrate that the larger the board of directors the more effectiveness, knowledge, capabilities, and expertise; thus this will lead to better performance (Buniamin et al., 2008; Jaafar \& El-Shawa, 2009; Nicholson \& Kiel, 2004). In the same vein (See, Abor \& Biekpe, 2007; Adams \& Mehran, 2012; Kajola, 2008; Kim et al., 2012; Tornyeva \& Wereko, 2012) argued that the large size of the board of directors is one of the most important corporate governance mechanisms that leads to obtain better performance. While, Bhagat \& Black (2002) and Sueyoshi et al. (2010) found insignificant association between board size and firm performance (Tobin's q). Therefore, we predict that increasing board size will be associated with increasing firm performance.

H1. There is a positive relationship between board size and the level of firm financial performance (market share).

\subsubsection{Board independency and Firm Performance}

Corporate governance literature proposes that the extent of non-executive (independent board) directors in the board of directors is promoted board effectiveness and this might help to alleviate and reduce agency problems by monitoring and controlling management's opportunistic behavior (Haniffa \& Hudaib, 2006).

Several previous studies examined the relationship between non-executive directors in the board of directors and 
firm performance (Abor \& Biekpe, 2007; Adams \& Mehran, 2012; Adnan et al., 2011; Agrawal \& Knoeber, 1998; Al-Hawary, 2011; Andres \& Vallelado, 2008; Balasubramanian et al., 2010; Bhagat \& Black, 2002; Chaghadari, 2011; Fama \& Jensen, 1983; Heracleous, 2001; Kajola, 2008; Klein, 1998; Kumar \& Singh, 2013; Mashayekhi \& Bazaz, 2008; Tornyeva \& Wereko, 2012; Yermack, 1996; Yoshikawa \& Phan, 2003; Zheka, 2006) and the results were inconsistent.

Empirical studies such as (Yermack, 1996; Laing \& Weir, 1999; Adnan et al., 2011; Chaghadari, 2011; Heracleous, 2001; Kajola, 2008; Yoshikawa \& Phan, 2003) find that board independence is not considered to be a significant factor that affects the level of firm performance. In the same vein, other studies in the literature such as Hermalin \& Weisbach (1991); Mehran (1995) Bhagat \& Black (2002) find that there is no relationship between board independent existence and firm performance.

On the other hand, (Agrawal \& Knoeber, 1998; Klein, 1998) find a negative effect of outside directors on firm performance. However, the majority of previous studies admit that the existence of non-executive directors on the board of directors builds up the independency of the board which facilitates them to effectively monitor and ensure the competition among executive managers which eventually promotes and maximizes firm performance (Abor \& Biekpe, 2007; Al-Hawary, 2011; Balasubramanian et al., 2010; Fama \& Jensen, 1983; Kumar \& Singh, 2013; Mashayekhi \& Bazaz, 2008; Tornyeva \& Wereko, 2012; Zheka, 2006). Based on this literature, the following hypotheses are developed:

$\mathrm{H}_{2}$ : There is a positive relationship between independent board and the level of firm financial performance (market share).

\subsubsection{CEO Duality and Firm Performance}

Jensen \& Meckling (1976) argue against CEO duality role where making decision management and control under one person increases boards' non-effectiveness in monitoring. In that, companies that have one person serving as both chairman and chief executive officer are having CEO duality, whereas this case leads to be more managerially dominated (Ho \& wang, 2001). When there is no separation in the position of CEO (the general manager) and chairman of the board, it calls CEO duality. It is such a vital monitoring mechanism based on agency theory (Grant, 2003; Chaghadari, 2011). The good feature for non-duality lies in weakening CEO power and higher board oversight. One of key theories that brought it to bear is agency theory and thus CEO duality becomes as an attractive subject for academics and scholarly. For instance, Dalton et al. (1998) explain that agency theory has been concerned extremely with the preference based on the separation between CEO and board chairman position because duality increases entrenchment of CEO and consequently reduces the monitoring effectiveness in the board of directors. The presence of duality in leadership could even contribute to the lack of transparency and accountability within the company. According to the essence and idea of agency theory, Fama \& Jensen (1983) show that firm with non CEO duality performs better than those having no separation. In the same orientation, Baliga et al. (1996) argue that the duality of CEO-Chairman has a little and very weak evidence related to its effect on firm performance. Nevertheless, to appoint one person to be chairman and CEO will lead to entrench the decision making and power by such a person which eventually affects board ability in doing effective control. In that, firms with the CEO duality offers greater power to one person which enables him/her to make decisions that do not maximize the shareholder's wealth. However, Chaganti et al. (1985) find no significant relationship between CEO duality and firm performance. In the same vein, (Rechner \& Dalton, 1989; Baliga et al., 1996; Laing \& Weir, 1999; Heracleous, 2001; Yoshikawa \& Phan, 2003; Mashayekhi $\&$ Bazaz, 2008) admit that there is no significant effect of CEO duality on firm performance. Neverthless, some other studies in the literature had opposite finding such as (Balasubramanian et al., 2010; Kajola, 2008; Tornyeva $\&$ Wereko, 2012) who find there is a positive relationship between CEO duality and firm performance.

On the other hand, several previous studies (Grove et al., 2011; Bai et al., 2004; Chaghadari, 2011; Rechner \& Dalton, 1991; Jensen, 1993; Yermack, 1996; Zheka, 2006) find that when there is no duality in CEO-chairman, firm performance will be enhanced. Therefore, it is hypothesized that:

$\mathrm{H}_{3}$ : There is a positive relationship between companies which do not have CEO duality and market share.

\section{Methodology}

\subsection{Source of Data Collection and Variables Measurement}

The current study deals with a sample consisting of a non-financial sector for listed Jordanian firms as cross-sectional study through collecting the primary data from the annual reports for the year 2011. We chose this year because the data is available and sufficient to serve the aim of this study as this study avoids involving financial sector because such a sector has its own different characteristics and regulations that make it differ 
from the other two sectors (Alkhatib \& Marji, 2012). We collected accounting and other useful data for the independent and dependent variables that served the current study to achieve its aim. The current study is the first to measure the dependent variable; financial performance via market share. The internal corporate governance mechanisms namely: the board size (BOD), the board independent/the independency (INED) and CEO duality (CEO duality) as independent variables and the dependent one is market share. In addition, firm size (Co size) is the control variable. Table 1 shows variables measurement summary.

Table 1. Summary of variables measurement

\begin{tabular}{llll}
\hline NO & Variables & Acronym & Measurement \\
\hline 1 & $\begin{array}{l}\text { Dependent Variable } \\
\text { Market Share (\%) } \\
\text { Independent Variables }\end{array}$ & MARKETSHARE & $\begin{array}{l}\text { Market Share is measured as net sales divided by the total } \\
\text { sales of the industry. }\end{array}$ \\
2 & $\begin{array}{l}\text { Board Size (number) } \\
3\end{array}$ & BOD & $\begin{array}{l}\text { The number of directors on the board of directors. } \\
\text { Outside director is the number of outside directors on the } \\
\text { board. } \\
\text { Whether or not the chairman is also the CEO during the } \\
\text { year, where it will take the value of "1" if the CEO is also } \\
\text { the chairman of the board, and "0" otherwise. }\end{array}$ \\
4 & CEO Duality (number) & CEO duality & Control Variable \\
5 & Firm Size (number) & Co size & Natural logarithmic of the firm's total assets. \\
\hline
\end{tabular}

\section{Results and Discussions}

\subsection{Descriptive Analysis}

This section presents the descriptive analysis of the research variables; dependent and independent variables for the 109 non-financial companies listed at Amman Stock Exchange (ASE) through using descriptive statistics such as mean, standard deviation, minimum and maximum. Table 2 shows the distribution of the variables. Based on the results of descriptive statistics, the dependent variable which is financial performance (market share) showed that the mean market share of Jordanian industrial and service companies is $45.21 \%$ with a standard deviation of 0.286 . Moreover, minimum rate of market share in the Jordanian non-financial companies is $7.9 \%$ with highest level of market share equal to $92 \%$. In addition, the descriptive analysis for the independent variable (corporate governance mechanisms shows that the average size of board of directors for the entire sample is about nine members (mean $=8.81$ ) with a standard deviation of 3.204. For the board independence of the companies in the sample the result reveals that the mean is $39.5 \%$ with a standard deviation of 3.755 . Also the results of descriptive analysis revealed that of the 109 companies of the sample, $17 \%$ the same person acts both the board chairman and the CEO positions. In Table 2, the results also show that the values for the skewness and kurtosis reveal that our sample is normally distributed because they are within the range of normality for both skewness and kurtosis. Brooks (2014) demonstrates that the normality of data could be achieved if standard kuartosis is within \pm 3 and standard skewness \pm 1.96 . In addition, the current study did not resort to choose or add industry category a control variable regarding the matter of different nature of the companies' work that exist within the sector as long as it calculates the market share for industrial and service sectors according to the companies involved in key industries, whether in service or industrial sector. It is worth mentioning that both industrial and service sectors include a set of industries (companies) having different activities and moves. In industrial sector for example: Pharmaceutical, medical industries, chemical industries, etc. and in the service sector: Health Care Services, Educational Services, etc. Thus, in order to measure market share, the current study takes into consideration the total sales of the companies that belong to the same industry and then calculates the ratio of each company's sales to total sales to reach the market share of this industry and thus this market share is calculated for each company in the sector to which it belongs. However, the current study resorted to add a financial control variable expressed by the natural logarithm of the book value of total assets as a proxy for firm size as used by (Anderson \& Reeb, 2003; Adams \& Mehran, 2012). In that, we use control variable for market share because we cannot compare the market share for the large company with that small one unless we avoid the difference in size. 
Table 2. Descriptive analysis

\begin{tabular}{lllllll}
\hline Variables & Mean & Std. Dev. & Minimum & Maximum & Skewness & Kurtosis \\
\hline Market share & .452 & .286 & .079 & .920 & .142 & -.898 \\
BOD & 8.81 & 3.204 & 3 & 15 & .434 & -1.409 \\
INED & .394 & .375 & .000 & 1.000 & 1.741 & 1.050 \\
CEO duality & .17 & .381 & 0 & 1 & .391 & -1.259 \\
\hline
\end{tabular}

\subsubsection{Descriptive Statistics of Board of Director}

Table 3 describes the percentage of board size on the firm performance. The descriptive statistic showed that only 22 companies have 7 members in the board with a percentage of 20.2, and 18 companies have 9 members in the board of directors with a percentage of 16.5. Moreover the descriptive analysis showed that 14 companies have 5 members with percentage of 12.8. On the other hand, the descriptive analysis also revealed that 2 companies have 8 members with a percentage of 1.8. Also there are 3 companies having 6 members with a percentage of 2.8. The table showed there are three frequencies with 4 companies. The first one has 3 members; the second one has 4 members, while the third group showed that 4 companies have 15 members. The percentage of these frequencies is 3.7 .

Table 3. Statistics of board size

\begin{tabular}{llll}
\hline & Frequency & Percent & Valid Percent \\
\hline 3 Valid & 4 & 3.7 & 3.7 \\
4 & 4 & 3.7 & 3.7 \\
5 & 14 & 12.8 & 12.8 \\
6 & 3 & 2.8 & 2.8 \\
7 & 22 & 20.2 & 20.2 \\
8 & 2 & 1.8 & 1.8 \\
9 & 18 & 16.5 & 16.5 \\
10 & 6 & 5.5 & 5.5 \\
11 & 11 & 10.1 & 10.1 \\
12 & 8 & 7.3 & 7.3 \\
13 & 7 & 6.4 & 6.4 \\
14 & 6 & 5.5 & 5.5 \\
15 & 4 & 3.7 & 3.7 \\
\hline
\end{tabular}

Table 4 describing the percentage for the board size on the companies shows that only 22 companies have the size board less than 5 members with 20.2 percent and 87 companies have the size board that is above 5 members with 79.8 percent. The descriptive statistic showed that most of the non-financial companies in Jordan have a majority of board size that above 5 members in the board.

Table 4. Frequency of board size

\begin{tabular}{llll}
\hline & Frequency & Percent & Valid Percent \\
\hline Less than 5 & 22 & 20.2 & 20.2 \\
Above 5 & 87 & 79.8 & 79.8 \\
\hline
\end{tabular}

\subsubsection{Descriptive Statistics of Board Independent/Non-executive Directors}

Table 5 reports the independent members in board of directors in non-financial Jordanian companies. It shows that the percentage of independent board was between $0.000-1.000$ percent. The table shows there is 51 companies that have an independent board between .000 to .222 percent. Also there are 18 companies that have an independent board between .250 to .555 . Moreover, there are 14 companies having independent members 
between 0.571 to 0.800 percent. The table further shows that there are 8 companies that have an independent board from 0.818 to 0.888 percent. In addition, there are other 18 companies that have .900 to 1.000 percent of independent members in the board. Finally, the descriptive statistic shows that most of the non-financial companies in Jordan have a majority of independent boards between .000 to .222 .

Table 5. Descriptive statistics of Independent board

\begin{tabular}{llll}
\hline & Frequency & Percent & Valid Percent \\
\hline Valid .000 to .222 & 51 & 46.8 & 46.8 \\
.250 to .555 & 18 & 16.4 & 16.4 \\
.571 to .800 & 14 & 12.7 & 12.7 \\
.818 to .888 & 8 & 9.9 & 9.9 \\
.900 to 1.000 & 18 & 14.2 & 14.2 \\
\hline
\end{tabular}

\subsubsection{Descriptive Statistics (Frequency) CEO Duality}

Table 6 shows that the CEO duality in the non-financial companies in Jordan was 17.4 percent for 19 companies, while 82.6 percent for the companies that do not have CEO duality were 90 companies. The descriptive statistic shows that most of the non-financial companies in Jordan have a majority of non CEO duality.

Table 6. Frequency of CEO duality

\begin{tabular}{llll}
\hline & Frequency & Percent & Valid Percent \\
\hline Duality & 19 & 17.4 & 17.4 \\
Non duality & 90 & 82.6 & 82.6 \\
\hline
\end{tabular}

\subsubsection{Market Share Statistics}

Table 7 reports the market share in Jordanian's non-financial companies. It shows that the percentage of market share was between $0.079-0.92$ percent. The table reveals that there are 22 companies that have market share between .079 to .154 percent. Also there are 19 companies that have market share between .163 to .300. Furthermore, there are 20 companies having market share between 0.325 to 0.431 percent. The table further shows that there are also 20 companies that have market share but it is from 0.439 to 0.707 percent. Also, there are 28 companies having .768 to.920 percent of market share. Finally, the descriptive statistic demonstrates that most of the non-financial companies in Jordan have a majority of market share between .768 to .920.

Table 7. Descriptive statistics of market share

\begin{tabular}{llll}
\hline & Frequency & Percent & Valid Percent \\
\hline Valid .079 to .154 & 22 & 19.8 & 19.8 \\
.163 to .300 & 19 & 17.4 & 17.4 \\
.325 to .431 & 20 & 18.5 & 18.5 \\
.439 to .707 & 20 & 18.5 & 18.5 \\
.768 to .920 & 28 & 25.8 & 25.8 \\
\hline
\end{tabular}

\subsection{Correlation Analysis}

The correlation between the dependent and independent variables is shown in Table 8. The result shows that two independent variables have negative relationship with market share and only one independent variable (CEO duality) has a positive relationship with market share, with values (BOD -.955), (INED -.161), (CEO duality.074). The table shows that board size has a highly negative relationship with market share with value -.955. Moreover, we examined the level of multicollinearity between the independent variables which should be less than $80 \%$ as suggested by Yoshikawa \& Phan (2003). We found the data didn't have multicollinearity problems, which often require $80 \%$ or more to indicate that the correlations between the independent variables have multicollinearity problems. The table reports the correlations of the variables. In addition, we examined the 
multicollinearity through two other indicators, namely; Tolerance and Variance Inflation Factor (VIF) as shown in Table 9. It shows that all tolerance values for the variables are more than 0.1 with VIF values that is less than 10 , as suggested by (Dias et al., 2011; Hair et al., 2010; Melagraki et al., 2009; Coyne et al., 2004). Even though other studies such as Shihab et al., (2010) set the maximum value of Variance Inflation Factor (VIF) to be 2.5, the current study reached such a level that didn't exceed 2.5. In other words, all results indicate that data in the current study are absence of multicollinearity thus the model contains no multicollinearity.

Table 8. Correlations between variables

\begin{tabular}{llllll}
\hline & BOD & INED & CEO duality & Co size & Market share \\
\hline BOD & 1 & & & & \\
INED & $.195^{*}$ & 1 & & & \\
CEO duality & -.109 & -.093 & 1 & & \\
Co size & .337 & .043 & -.125 & 1 & 1 \\
Market share & $-.955^{* *}$ & -.161 & .074 & -.311 & 1 \\
\hline
\end{tabular}

Level of significance $* \mathrm{p}<.10, * * \mathrm{p}<.05$

\subsection{Multiple Linear Regression Analysis}

In the current study, linear regression analysis was used to determine the direction of the relationship between the predictors variables and criterion as a common statistical method that have been used in several science disciplines (Nathans et al., 2012).

Table 9. Multicollinearity test

\begin{tabular}{lll}
\hline Variables & Tolerance Value & VIF \\
\hline Board size & .851 & 1.175 \\
Board independency & .956 & 1.046 \\
CEO duality & .974 & 1.027 \\
Co size & .878 & 1.139 \\
\hline
\end{tabular}

\subsubsection{Regression Results of Model (Based on Firm Performance Measured by Market Share)}

In Table 10, regression results show that $\mathrm{R}$ square value is .914 for market share. This means that $\mathrm{R}$ square value is explaining $91 \%$ of the independent variables (BOD, INED and CEO duality) on the dependent one (market share).

Table 10. R Square of Market share

\begin{tabular}{ll}
\hline Model & Market share \\
\hline R Square & .914 \\
Sig F Change & .000 \\
\hline
\end{tabular}

The autocorrelation is examined by using Durbin Watson (DW) test. In this respect, the Durbin Watson of 1.75 is a good value since it falls between the acceptable range of 1.5-2.5 as suggested by Knoke (2003), and it shows there is no autocorrelation problem in data.

In Table 11, regression statistical analysis was run between all the variables that have been chosen in the current study represented by the independent variables, control variable, and the dependent variable of market share; the output shows that two variables have a negative relationship with market share (BOD; $\beta=-.967$, CEO duality; $\beta$ $=-.028)$, while the others: Co size (log of total assets) and INED have positive relationship with market share (INED; $\beta=.024$, Co size; $\beta=.010$ ).

The results of regression analysis show that Co size is insignificant with financial performance (market share). The testing hypotheses of the current study found surprising results regarding the association between every 
independent variable and dependent ones, as shown in Table 11. There is a highly significant negative impact relationship between board size (BOD) and firm financial performance (market share) at $\mathrm{P}<.00, \beta=-.967$. In that, small size of board of directors is associated with higher financial performance. This result provides support to prior studies in Malaysia; Adnan et al. (2011), Haniffa \& Hudaib (2006) and a study in Singapore and Malaysia; Mak \& Kusnadi (2005) and in India; Kumar \& Singh (2013) and in Iran; Mashayekhi \& Bazaz (2008) and in Bangladesh; Rashid et al. (2010) and in the US; Yermack (1996), Jensen (1993). In that, this result is consistent with previous studies that were done in both developed and developing countries. However, this result is inconsistent with H1, BOD is positively correlated with financial performance. Therefore, hypothesis H1 is not supported. The reason of this result reflects that small size of board of directors in non-financial companies in Jordan is more active and this leads to better outcome than large one (Adnan et al., 2011). Such a result matches with the result in the previous studies which admit that small size of boards increases and improves the communication and coordination problems.

H2 states that INED is positively associated with firm performance. Although the direction of this hypothesis was correct, the hypothesis was not supported because it reveals that the relationship between independent board (INED) and firm performance is insignificant at $\mathrm{P}>.1, \beta=.024$. Nevertheless, this result is similar to some of previous studies in the literature that found no relationship between independent board of directors and financial performance, which means the board independence, is not considered to be a significant factor that affects firm performance. Some of these studies were in developing countries like (Adnan et al., 2011; Chaghadari, 2011; Kajola, 2008) and the others in developed countries such as (Adams \& Mehran, 2012; Bhagat \& Black, 2002; Hermalin \& Weisbach, 1991; Mehran, 1995; Yermack, 1996; Heracleous, 2001; Yoshikawa \& Phan, 2003). We believe that the potential reason to explain this result is that board independency doesn't matter. In that, independent and non-independent board of directors is equally good or might be bad to represent the wealth of stakeholders. Finally, our study predicted and hypothesized the companies that do not have duality are positively linked with firm performance (market share). The result shows that the hypothesized direction was correct but it was found insignificant relationship $(\mathrm{P}>.1, \beta=-.028)$. However, the insignificant result between the $\mathrm{CEO} /$ mechanism duality and firm performance is consistent with some studies that have been done previously in the literature, for example, Mashayekhi \& Bazaz (2008) and Chaganti et al. (1985), who found insignificant relationship between CEO duality and firm performance.

Ramdani \& Witteloostuijn (2010) argue that from perspective of agency theory, the Chief Executive Officer and chairman of the board of directors should be held by different persons so that the separation between control responsibility and management could be achieved and leads to enhancement of firm performance. In our sample, although the majority of non-financial companies tended to apply separation between CEO and chairman (where 82.6 percent for the companies do not have CEO duality which is equal to 90 companies), there was an insignificant relationship between this mechanism and firm performance. Our possible explanation for this result is that the cost of implementation of this mechanism exceeds its benefits which consequently lead to lack of effectiveness of this mechanism, which might also be affected due to some environmental variables which can be considered critical. Moreover, another possible reason for this result is that within Jordanian company, it is the substantial shareholder who is likely to be a person who serves as both CEO and board chairman, so it does make sense if the two jobs are separated or otherwise.

Table 11. Regression statistical analysis

\begin{tabular}{llll}
\hline \multicolumn{4}{l}{ Market share Standardized Coefficients } \\
\hline Variables & Beta & t- value & Sig. \\
BOD & $-.967^{* * *}$ & -31.102 & .000 \\
INED & .024 & .833 & .407 \\
CEO duality & -.028 & -.963 & .338 \\
Co size & .010 & -.028 & .747
\end{tabular}

Level of significance $* \mathrm{p}<.10, * * \mathrm{p}<.05, * * * \mathrm{p}<.01$ 


\section{Conclusion}

In the last three decades, and even more recently, corporate governance has become a very vital and important issue to the corporation including non-financial sector and its performance. The business world has faced many scandals and failures at the level of all sectors such as Enron and Arthur Andersen and Marconi. Such scandals and others have brought about a shock for both developed and developing economies and given so much attention to investors and other stakeholders to beware of dealing with corporations, non-financial sector, which have poor level of corporate governance.

There are several studies that have dealt with the relationship between corporate governance and firm performance, however, it should be noted that while the argument over corporate governance mechanisms role has been rich in rhetoric, there have been practically no empirical studies brought to bear on investigating the relationship between corporate governance and firm performance by choosing market share as a measurement of firm financial performance. This study uses Jordan data to analyze whether companies performed more when they have large board size, have independent non-executive directors, and have no CEO duality. In that, this study investigates the relationship of the firms' internal corporate governance mechanism represented by board of directors attribute (board size, board independency, and duality) and Jordanian Companies' Financial Performance.

In order to test the hypotheses between these mechanisms and financial performance, we use data in the annual reports for the fiscal year 2011 as cross section analysis of a sample of 109 listed Jordanian industrial and service companies from the website of Amman Stock Exchange (ASE).

We find contradiction in the common belief that non duality/duality leadership structures and more/less independent boards lead to enhancement of firm performance, which indicate that agency theory is unable/limited in its illustration of the link between these two board characteristics and firm performance. Our findings revealed a negative effect of board size on firm performance in non-financial companies in Jordan. On the issue of CEO duality, we reveal that although the majority of Jordanian firms have separated the CEO from chairman role through appointment of two different people occupying such positions, the result shows there is no impact of such mechanism on firm performance. Our possible explanation for this result is that the cost of implementation of this mechanism exceeds its benefits which consequently lead to lack of effectiveness of this mechanism, which might also be affected due to some environmental variables which can be considered critical. This result is supported by the findings of some previous studies such as Chaganti et al. (1985), Rechner \& Dalton (1989), and Yoshikawa \& Phan (2003).

Our study also reveals insignificant relationship between independent board (outside directors) and firm performance. We believe that the potential reason to explain such result is that independent board doesn't matter. In that, independent and non-independent board of directors is equally good or might be bad to represent the wealth of stakeholders. This result is in conflict with that of Agrawal \& Knoeber, (1998) who found that the higher percentage of dependent board the lower firm performance and vice versa. In addition, our result is incompatible with that of Abor \& Biekpe, (2007) and Balasubramanian et al. (2010) who found that independent board promotes and maximizes firm performance. However, this result is similar to that of (Chaghadari, 2011; Heracleous, 2001; Kajola, 2008; Bhagat \& Black, 2002).

Our regression results show that there is a negative and significant relationship between board size and firm performance. The reason of this result reveals that small size of board of directors in non-financial companies in Jordan is more active and this leads to better outcome than large one. Some of prior studies admitted this result such as those by Adnan et al. (2011), Haniffa \& Hudaib (2006), Kumar \& Singh (2013), Rashid et al. (2010), Yermack (1996), Jensen (1993). On the other hand, such result contradicts with that of (Abor \& Biekpe, 2007; Adams \& Mehran, 2012; Jaafar \& El-Shawa, 2009) who found that the board size has a positive and significant relationship with firm performance.

This study is not without limitation, and this limitation must be taken into consideration when explaining its results. It must be admitted that this analysis is limited to the non-financial companies in one of emerging countries, Jordan. Thus, for future research there is a need to examine whether the same findings can be found by examining these variables in different countries that have different legal systems because as mentioned by Sanchez-Marin \& Baixauli (2014) that the effectiveness of corporate governance is different between countries especially between developed and developing ones. Moreover, it should be taken into account that the current study focuses on the corporate governance mechanisms represented by board composition in one of the developing countries while its new idea should be tested also in the developed countries to identify the effect of such variables on firm financial performance measurement via market share, where no previous study did so. 


\section{References}

Abor, J., \& Biekpe, N. (2007). Corporate governance, ownership structure and performance of SMEs in Ghana: Implications for financing opportunities. Corporate governance, 7(3), 288-300. http://dx.doi.org/10.1108 /14720700710756562

Adams, R. B., \& Mehran, H. (2012). Bank board structure and performance: Evidence for large bank holding companies. Journal of Financial Intermediation, 21(2), 243-267. http://dx.doi.org/10.1016/j.jfi.2011.09.002

Adnan, M. A., Htay, S. N. N., Rashid, A., Majdi, H., Meera, M., \& Kameel, A. (2011). A panel data analysis on the relationship between corporate governance and bank efficiency. Journal of Accounting, Finance and Economics, 1(1), 1-15.

Agrawal, A., \& Knoeber, C. R. (1998). Managerial compensation and the threat of takeover. Journal of Financial Economics, 47(2), 219-239. http://dx.doi.org/10.1016/S0304-405X(97)00044-5

Alabdullah, T. T. Y., Yahya, S., \& Ramayah, T. (2014). Corporate Governance Development: New or Old Concept. European Journal of Business and Management, 6(7), 312-315.

Al-Haddad, W., Alzurqan, S. T., \& Al-Sufy, F. J. (2011). The effect of corporate governance on the performance of Jordanian industrial companies: An empirical study on Amman Stock Exchange. International Journal of Humanities and Social Science, 1(4), 55-69.

Al-Hawary, S. (2011). The Effect of Banks Governance on Banking Performance of the Jordanian Commercial Banks: Tobin's Q Model" An Applied Study. International Research Journal of Finance and Economics, 71, $35-45$.

Alkhatib, K., \& Marji, Q. (2012). Audit reports timeliness: Empirical evidence from Jordan. Procedia-Social and Behavioral Sciences, 62, 1342-1349. http://dx.doi.org/10.1016/j.sbspro.2012.09.229

Al-Qaisi, K. (2013). The effect of the financial crisis on the Jordanian industrial sector. International Journal of Finance \& Banking Studies, 2(1), 43-47.

Amman Stock Exchange. (2011). Companies' Guide. Retrieved from http://www.ase.com.jo/

Anderson, R. C., \& Reeb, D. M. (2003). Founding-family ownership and firm performance: Evidence from the S\&P 500. The journal of finance, 58(3), 1301-1327. http://dx.doi.org/10.1111/1540-6261.00567

Andres, P. D., \& Vallelado, E. (2008). Corporate governance in banking: The role of the board of directors. Journal of banking \& finance, 32(12), 2570-2580. http://dx.doi.org/10.1016/j.jbankfin.2008.05.008

Aras, G., \& Crowther, D. (2008). Governance and sustainability: An investigation into the relationship between corporate governance and corporate sustainability. Management Decision, 46(3), 433-448. http://dx.doi.org/ $10.1108 / 00251740810863870$

Bai, C. E., Liu, Q., Lu, J., Song, F. M., \& Zhang, J. (2004). Corporate governance and market valuation in China. Journal of Comparative Economics, 32(4), 599-616. http://dx.doi.org/10.1016/j.jce.2004.07.002

Balasubramanian, N., Black, B. S., \& Khanna, V. (2010). The relation between firm-level corporate governance and market value: A case study of India. Emerging Markets Review, 11(4), 319-340. http://dx.doi.org/10. 1016/j.ememar.2010.05.001

Baliga, B., Moyer, R. C., \& Rao, R. S. (1996). CEO duality and firm performance: What's the fuss? Strategic Management Journal, 17(1), 41-53. http://dx.doi.org/10.1002/(SICI)1097-0266(199601)17:1<41::AIDSMJ784>3.0.CO;2-\#

Bauer, R., Frijns, B., Otten, R., \& Tourani-Rad, A. (2008). The impact of corporate governance on corporate performance: Evidence from Japan. Pacific-Basin Finance Journal, 16(3), 236-251. http://dx.doi.org/10. 1016/j.pacfin.2007.05.001

Bauer, R., Guenster, N., \& Otten, R. (2004). Empirical evidence on corporate governance in Europe: The effect on stock returns, firm value and performance. Journal of Asset Management, 5(2), 91-104. http://dx.doi.org/ 10.1057/palgrave.jam.2240131

Black, B. S., Love, I., \& Rachinsky, A. (2006). Corporate governance indices and firms' market values: Time series evidence from Russia. Emerging Markets Review, 7(4), 361-379. http://dx.doi.org/10.1016/j. ememar.2006.09.004

Brooks, C. (2014). Introductory econometrics for finance. Cambridge university press, New York. 
Brown, L. D., \& Caylor, M. L. (2006). Corporate governance and firm valuation. Journal of Accounting and Public Policy, 25(4), 409-434. http://dx.doi.org/10.1016/j.jaccpubpol.2006.05.005

Cadbury Committee. (1992). Report of the committee on the financial aspects of corporate governance. Gee and Co., London.

Chaganti, R. S., Mahajan, V., \& Sharma, S. (1985). Corporate Board Size, Composition and Corporate Failures in Retailing Industry. Journal of Management Studies, 22(4), 400-417. http://dx.doi.org/10.1111/j.1467 $-6486.1985 . t b 00005 . x$

Chaghadari, M. F. (2011). Corporate Governance and Firm Performance. International Conference on Sociality and Economics Development IPEDR, 10, 485-489.

Chen, K. C., Chen, Z., \& Wei, K. C. (2009). Legal protection of investors, corporate governance, and the cost of equity capital. Journal of Corporate Finance, 15(3), 273-289. http://dx.doi.org/10.1016/j.jcorpfin.2009. 01.001

Cheung, Y. L., Connelly, J. T., Limpaphayom, P., \& Zhou, L. (2007). Do investors really value corporate governance? Evidence from the Hong Kong market. Journal of International Financial Management \& Accounting, 18(2), 86-122. http://dx.doi.org/10.1111/j.1467-646X.2007.01009.x

Chhibber, P. K., \& Majumdar, S. K. (1999). Foreign Ownership and Profitability: Property Rights, Control, and the Performance of Firms in Indian Industry. The Journal of Law and Economics, 42(1), 209-238. http://dx.doi.org/10.1086/467423

Clarke, M., Seng, D., \& Whiting, R. H. (2011). Intellectual capital and firm performance in Australia. Journal of Intellectual Capital, 12(4), 505-530. http://dx.doi.org/10.1108/14691931111181706

Cooke, F. L. (2001). Human resource strategy to improve organizational performance: A route for firms in Britain? International Journal of Management Reviews, 3(4), 321-339. http://dx.doi.org/10.1111/1468-2370. 00071

Coyne, K. S., Payne, C., Bhattacharyya, S. K., Revicki, D. A., Thompson, C., Corey, R., \& Hunt, T. L. (2004). The impact of urinary urgency and frequency on health-related quality of life in overactive bladder: Results from a national community survey. Value in health, 7(4), 455-463. http://dx.doi.org/10.1111/j.1524-4733. 2004.74008.x

Cui, H., \& Mak, Y. T. (2002). The relationship between managerial ownership and firm performance in high R\&D firms. Journal of Corporate Finance, 8(4), 313-336. http://dx.doi.org/10.1016/S0929-1199(01) 00047-5

Dias, R. A. P., Petrini, J., Ferraz, J. B. S., Eler, J. P., Bueno, R. S., da Costa, A. L. L., \& Mourão, G. B. (2011). Multicollinearity in genetic effects for weaning weight in a beef cattle composite population. Livestock Science, 142(1), 188-194. http://dx.doi.org/10.1016/j.livsci.2011.07.016

Dittmar, A., \& Mahrt-Smith, J. (2007). Corporate governance and the value of cash holdings. Journal of Financial Economics, 83(3), 599-634. http://dx.doi.org/10.1016/j.jfineco.2005.12.006

Durnev, A., \& Kim, E. (2005). To steal or not to steal: Firm attributes, legal environment, and valuation. The Journal of Finance, 60(3), 1461-1493. http://dx.doi.org/10.1111/j.1540-6261.2005.00767.x

Eccles, R. G. (1990). The performance measurement manifesto. Harvard business review, 69(1), 131-137.

Eiteman, D. K., Stonehill, A. I., \& Moffett, M. H. (2009). Multinational business Finance. New York: Pearson.

Fama, E. F., \& Jensen, M. C. (1983). Separation of ownership and control. Journal of law and economics, 26, 301-325. http://dx.doi.org/10.1086/467037

Franck, P., \& Sundgren, S. (2012). Determinants of internal governance quality: Evidence from Sweden. Managerial Auditing Journal, 27(7), 639-665. http://dx.doi.org/10.1108/02686901211246796

Garay, U., \& González, M. (2008). Corporate governance and firm value: The case of Venezuela. Corporate governance: An international review, 16(3), 194-209. http://dx.doi.org/10.1111/j.1467-8683.2008.00680.x

Gedajlovic, E., \& Shapiro, D. M. (2002). Ownership structure and firm profitability in Japan. Academy of Management Journal, 45(3), 565-575. http://dx.doi.org/10.2307/3069381

Gompers, P., Ishii, J., \& Metrick, A. (2003). Corporate Governance and Equity Prices. Quarterly Journal of Economics, 118, 107-155. http://dx.doi.org/10.1162/00335530360535162 
Grant, G. H. (2003). The evolution of corporate governance and its impact on modern corporate America. Management Decision, 41(9), 923-934. http://dx.doi.org/10.1108/00251740310495045

Grove, H., Patelli, L., Victoravich, L. M., \& Xu, P. T. (2011). Corporate governance and performance in the wake of the financial crisis: Evidence from US commercial banks. Corporate Governance: An International Review, 19(5), 418-436. http://dx.doi.org/10.1111/j.1467-8683.2011.00882.x

Guo, L., Smallman, C., \& Radford, J. (2013). A critique of corporate governance in China. International Journal of Law and Management, 55(4), 257-272. http://dx.doi.org/10.1108/IJLMA-10-2011-0012

Hair, J. F., Anderson, R. E., Tatham, R. L., \& Black, W. C. (2010). Multivariate data analysis. New York: Prentice-Hall, Upper Saddle River, NJ.

Haniffa, R., \& Hudaib, M. (2006). Corporate governance structure and performance of Malaysian listed companies. Journal of Business Finance \& Accounting, 33(7-8), 1034-1062. http://dx.doi.org/10.1111/j. 1468-5957.2006.00594.x

Hansen, G. S., \& Wernerfelt, B. (1989). Determinants of firm performance: The relative importance of economic and organizational factors. Strategic management journal, 10(5), 399-411. http://dx.doi.org/10.1002/smj. 4250100502

Hassan, S. U., \& Ahmed, A. (2012). Corporate Governance, Earnings Management and Financial Performance: A Case of Nigerian Manufacturing Firms. American International Journal of Contemporary Research, 2(7), 214-226.

Heracleous, L. (2001). What is the impact of corporate governance on organizational performance? Corporate Governance: An International Review, 9(3), 165-173. http://dx.doi.org/10.1111/1467-8683.00244

Hermalin, B. E., \& Weisbach, M. S. (1991). The effects of board composition and direct incentives on firm performance. Financial management, 20, 101-112. http://dx.doi.org/10.2307/3665716

Hiraki, T., Inoue, H., Ito, A., Kuroki, F., \& Masuda, H. (2003). Corporate governance and firm value in Japan: Evidence from 1985 to 1998. Pacific-Basin Finance Journal, 11(3), 239-265. http://dx.doi.org/10.1016/S 0927-538X (03)00023-4

Ho, S. S., \& Wong, K. S. (2001). A study of the relationship between corporate governance structures and the extent of voluntary disclosure. Journal of International Accounting, Auditing and Taxation, 10(2), 139-156. http://dx.doi.org/10.1016/S1061-9518(01)00041-6

Hoque, Z., \& James, W. (2000). Linking balanced scorecard measures to size and market factors: Impact on organizational performance. Journal of management accounting research, 12(1), 1-17. http://dx.doi.org/10. 2308/jmar.2000.12.1.1

Jaafar, A., \& El-Shawa, M. (2009). Ownership concentration, board characteristics and performance: Evidence from Jordan. Research in accounting in emerging economies, 9, 73-95. http://dx.doi.org/10.1108/S1479 $-3563(2009) 0000009005$

Jensen, M. C. (1993). The modern industrial revolution, exit, and the failure of internal control systems. The Journal of Finance, 48(3), 831-880. http://dx.doi.org/10.1111/j.1540-6261.1993.tb04022.x

Jensen, M. C., \& Meckling, W. H. (1976). Theory of the firm: Managerial behavior, agency costs and ownership structure. Journal of Financial Economics, 3, 305-360. http://dx.doi.org/10.1016/0304-405X(76)90026-X

Kajola, S. O. (2008). Corporate governance and firm performance: The case of Nigerian listed firms. European Journal of Economics, Finance and Administrative Sciences, 14(14), 16-28.

Kim, S. H., Cha, J. M., Cichy, R. F., Kim, M. R., \& Tkach, J. L. (2012). Effects of the size of the board of directors and board involvement in strategy on a private club's financial performance. International Journal of Contemporary Hospitality Management, 24(1), 7-25. http://dx.doi.org/10.1108/09596111211197773

Klapper, L. F., \& Love, I. (2004). Corporate governance, investor protection, and performance in emerging markets. Journal of Corporate Finance, 10(5), 703-728. http://dx.doi.org/10.1016/S0929-1199(03)00046-4

Klein, A. (1998). Firm Performance and Board Committee Structure. The Journal of Law and Economics, 41(1), 275-304. http://dx.doi.org/10.1086/467391

Knoke, T. (2003). Predicting red heartwood formation in beech trees (Fagus sylvatica L.). Ecological Modelling, 169(2), 295-312. http://dx.doi.org/10.1016/S0304-3800(03)00276-X

Kumar, N., \& Singh, J. P. (2013). Effect of board size and promoter ownership on firm value: Some empirical 
findings from India. Corporate Governance, 13(1), 88-98. http://dx.doi.org/10.1108/14720701311302431

Laing, D., \& Weir, C. M. (1999). Governance structures, size and corporate performance in UK firms. Management Decision, 37(5), 457-464. http://dx.doi.org/10.1108/00251749910274234

Mak, Y. T., \& Kusnadi, Y. (2005). Size really matters: Further evidence on the negative relationship between board size and firm value. Pacific-Basin Finance Journal, 13(3), 301-318. http://dx.doi.org/10.1016/j. pacfin.2004.09.002

Makhamreh, M. (2000). Corporate performance in Jordan: A study of the banking sector. The Arab Bank Review, 2(2), 40-48.

Marr, B., \& Schiuma, G. (2003). Business performance measurement-past, present and future. Management Decision, 41(8), 680-687. http://dx.doi.org/10.1108/00251740310496198

Martinsons, M., Davison, R., \& Tse, D. (1999). The balanced scorecard: A foundation for the strategic management of information systems. Decision support systems, 25(1), 71-88. http://dx.doi.org/10.1016/S 0167-9236(98)00086-4

Mashayekhi, B., \& Bazaz, M. S. (2008). Corporate governance and firm performance in Iran. Journal of Contemporary Accounting \& Economics, 4(2), 156-172. http://dx.doi.org/10.1016/S1815-5669(10)70033-3

Mayer, C. (1997). Corporate governance, competition, and performance. Journal of Law and Society, 24(1), 152-176. http://dx.doi.org/10.1111/1467-6478.00041

Mazzanti, M., Pini, P., \& Tortia, E. (2006). Organizational innovations, human resources and firm performance: The Emilia-Romagna food sector. The Journal of Socio-Economics, 35(1), 123-141. http://dx.doi.org/10. 1016/j.socec.2005.12.007

Mehran, H. (1995). Executive compensation structure, ownership, and firm performance. Journal of financial economics, 38(2), 163-184. http://dx.doi.org/10.1016/0304-405X(94)00809-F

Melagraki, G., Afantitis, A., Sarimveis, H., Koutentis, P. A., Kollias, G., \& Igglessi-Markopoulou, O. (2009). Predictive QSAR workflow for the in silico identification and screening of novel HDAC inhibitors. Molecular diversity, 13(3), 301-311. http://dx.doi.org/10.1007/s11030-009-9115-2

Mkrtchyan, A. (2012). The effect of director expertise on acquisition performance. Working paper, Penn State University.

Nathans, L. L., Oswald, F. L., \& Nimon, K. (2012). Interpreting multiple linear regression: A guidebook of variable importance. Practical Assessment, Research \& Evaluation, 17(9), 1-19.

Nicholson, G. J., \& Kiel, G. C. (2004). Breakthrough board performance: How to harness your board's intellectual capital. Corporate Governance, 4(1), 5-23. http://dx.doi.org/10.1108/14720700410521925

Oxenfeldt, A. R. (1959). How to use market-share measurement. Harvard Business Review, 37(1), 59-68.

Palacios-Marqués, D., Peris-Ortiz, M., \& Merigó, J. M. (2013). The effect of knowledge transfer on firm performance: An empirical study in knowledge-intensive industries. Management Decision, 51(5), 973-985. http://dx.doi.org/10.1108/MD-08-2012-0562

Ramdani, D., \& Witteloostuijn, A. V. (2010). The impact of board independence and CEO duality on firm performance: A quantile regression analysis for Indonesia, Malaysia, South Korea and Thailand. British Journal of Management, 21(3), 607-627. http://dx.doi.org/10.1111/j.1467-8551.2010.00708.x

Rashid, A., De Zoysa, A., Lodh, S., \& Rudkin, K. (2010). Board composition and firm performance: Evidence from Bangladesh. Australasian Accounting Business and Finance Journal, 4(1), 76-95.

Rechner, P. L., \& Dalton, D. R. (1989). The impact of CEO as board chairperson on corporate performance: Evidence vs. rhetoric. The Academy of Management Executive, 3(2), 141-143. http://dx.doi.org/10.5465/ AME.1989.4274764

Rechner, P. L., \& Dalton, D. R. (1991). CEO duality and organizational performance: A longitudinal analysis. Strategic Management Journal, 12(2), 155-160. http://dx.doi.org/10.1002/smj.4250120206

Sanchez-Marin, G., \& Baixauli, J. S. (2014). CEO reputation and top management team compensation: The moderating role of corporate governance. Management Decision, 52(3), 7. http://dx.doi.org/10.1108/MD $-09-2013-0453$

Shihab, E., Jiang, Z. M., Ibrahim, W. M., Adams, B., \& Hassan, A. E. (2010). Understanding the impact of code 
and process metrics on post-release defects: A case study on the eclipse project. Proceedings of the 2010 ACM-IEEE International Symposium on Empirical Software Engineering and Measurement, 1-10. Bolzano-Bozen, 2010, Italy. http://dx.doi.org/10.1145/1852786.1852792

Shleifer, A., \& Vishny, R. W. (1997). A survey of corporate governance. The journal of finance, 52(2), 737-783. http://dx.doi.org/10.1111/j.1540-6261.1997.tb04820.x

Sueyoshi, T., Goto, M., \& Omi, Y. (2010). Corporate governance and firm performance: Evidence from Japanese manufacturing industries after the lost decade. European Journal of Operational Research, 203(3), $724-736$. http://dx.doi.org/10.1016/j.ejor.2009.09.021

Tornyeva, K., \& Wereko, T. (2012). Corporate governance and firm performance: Evidence from the insurance sector of Ghana. European Journal of Business and Management, 4(13), 95-112.

Yermack, D. (1996). Higher market valuation of companies with a small board of directors. Journal of financial economics, 40(2), 185-211. http://dx.doi.org/10.1016/0304-405X(95)00844-5

Yoshikawa, T., \& Phan, P. H. (2003). The performance implications of ownership-driven governance reform. European Management Journal, 21(6), 698-706. http://dx.doi.org/10.1016/j.emj.2003.09.013

Zehir, C., Altindag, E., \& Acar, A. Z. (2011). The Effects of Relationship Orientation through Innovation Orientation on Firm Performance: An Empirical Study on Turkish Family-Owned Firms. Procedia-Social and Behavioral Sciences, 24, 896-908. http://dx.doi.org/10.1016/j.sbspro.2011.09.024

Zheka, V. (2006). Corporate governance and firm performance in Ukraine. Heriot-Watt University Centre for Economic Reform and Transformation Discussion Paper, 5, 1-68.

\section{Copyrights}

Copyright for this article is retained by the author(s), with first publication rights granted to the journal.

This is an open-access article distributed under the terms and conditions of the Creative Commons Attribution license (http://creativecommons.org/licenses/by/3.0/). 